\title{
ANALISIS FAKTOR-FAKTOR YANG MEMPENGARUHI KINERJA ANGGOTA KELOMPOK USAHA KECIL DAN MIKRO (UKM) BINAAN UP3HP DI KOTA BENGKULU
}

\author{
Romi Gunawan \\ Program Studi Akuntansi \\ Fakultas Ekonomi Universitas Dehasen Bengkulu
}

\begin{abstract}
ABSTRAK
Romi Gunawan; Tujuan penelitian untuk mengetahui kinerja anggota kelompok Binaan UP3HP dan untuk menganalisis pengaruh modal, umur, usia usaha dan pendidikan terhadap kinerja (omzet) anggota UP3HP di Kota Bengkulu. Alat analisis yang digunakan adalah multiple linier reggresion pada tingkat kepercayaan 95\% ( $\alpha=5 \%)$. Dari hasil penelitian diketahui bahwa omzet dari anggota kelompok binaan UP3HP masih tergolong kecil. Ada beberapa anggota yang telah lama menjalankan usaha namun memiliki omzet kecil. Hasil penelitian juga memperlihatkan bahwa variabel modal, umur, usia usaha dan pendidikan memiliki berpengaruh yang signifikan terhadap kinerja (omzet). Besarnya pengaruh tersebut dijelaskan oleh nilai koefisien regresi $\left(\mathrm{R}^{2}\right)$ sebesar $80 \%$.
\end{abstract}

\section{ABSTRACT}

Romi Gunawan; The research purpose to observe the performance of SME and to analyze the influence of capital, age's respondent, the age of SME and education toward omzet of UP3HP member in Bengkulu City. The analysis instrumen used is multiple liniear reggresion on the covident level of 95\%. From the researce know that omzet of the SME nurture by UP3HP stil in small clasification. there are some enterpreneur who have old enter prises common have small omzet. And than, capital, age`s respondent, the age of SME and education have significance's influence toward omzet. Extended of influence mentioned point out of determination coeffisient $\left(R^{2}\right)$ amount of $80 \%$.

Key words: Performance of SME, Omzet.

\section{PENDAHULUAN}

Di Indonesia usaha kecil telah membuktikan diri sebagai usaha bisnis yang mempunyai daya tahan yang relatif lebih kuat dibandingkan dengan usaha menegah dan besar, terutama pada era krisis moneter. Ketanan tersebut terutama disebabkan oleh penggunaan faktor produksi non impor. Selain itu usaha kecil juga mempunyai potensi pasar yang cukup besar dengan biaya produksi yang cukup rendah. Oleh karenanya produk dari usaha kecil akan terjangkau oleh golongan ekonomi menengah kebawah yang merupakan pasar terbesar di indonesia pada saat ini. Peranan usaha kecil pada bidang ketenaga kerjaan juga sangat penting. Hal ini disebabkan jumlah tenaga kerja yang bekerja atau mampu diserap oleh kelompok usaha kecil jauh lebih banyak dibandingkan dengan usaha menengah atau besar.

Mengingat pentingnya peranan yang tertumpu pada usaha kecil ini, pemerintah melakukan pembinaan terhadap kelompok usaha kecil. Pembinaan tersebut telah mengalami beberapa kali perubahan, semula pembinaan usaha kecil terpisah dengan pembinaan terhadap koperasi, kemudian dirubah menjadi satu bentuk pembinaan. Terakhir pembinaan terhadap usaha kecil dapat dilakukan oleh berbagai instansi pemerintah.

Berdasarkan PROPENAS (Program Pembangunan Nasional) Tahun 2000-2004 ditetapkan beberapa pokok pembinaan usaha kecil. Pokok-pokok pembinaan tersebut antara lain, program penciptaan iklim usaha yang kondusif, akses pada sumber daya yang produktif, dan pengembangan kewirausahaan yang mempunyai keunggulan kompetitif. Wujud dari 
pelaksanaan program tersebut adalah dengan pemberian bantuan secara materil maupun non materil (BKKSI, 2001: 2).

Di Bengkulu pembinaan terhadap usaha kecil dilakukan tidak hanya oleh instansi pemerintah tetapi juga swasta. Instansi-instansi pemerintah yang melakukan pembinaan terhadap usaha kecil antara lain, Dinas Pertanian, Dinas PERINDAG, BKKBN, dan Dinas Koperasi dan UMKM. Masing-masing instansi mempunyai program pembinaan yang belum tentu sama. Tentunya program pembinaan sesuai dengan metode dan tujuan yang ditetapkan oleh masingmasing instansi. Salah satu program pembinaan tersebut adalah program UP3HP binaan Dinas Pertanian.

UP3HP atau Unit Pelayanan Pengembangan Pengolahan Hasil Pertanian merupakan suatu mekanisme pembinaan yang bertujuan untuk memfasilitasi tumbuhnya industri pengelolaan skala kecil, menengah, dan industri rumah tangga. Program UP3HP dikembangkan di Kota Bengkulu sejak tahun 2001 dengan jumlah kelompok binaan sebanyak 12 kelompok, dimana tiap kelompok terdiri dari 2 sampai 10 orang anggota binaan. Jumlah kelompok itu terus berkembang sampai saat ini terdapat 61 kelompok binaan program UP3HP (Dinas Pertanian Kota Bengkulu: 2007)

Kinerja salah satu faktor yang menentukan keberhasilan program UP3HP, karena tujuantujuan program UP3HP akan tercapai dengan kinerja anggota binaan-binaan yang baik. Namun sebaliknya, jika kinerja buruk maka tujuan UP3HP akan sulit dicapai. Kinerja ini dapat diukur dengan besarnya omzet dari usaha masing-masing kelompok UP3HP. Faktor utama yang mempengaruhi omzet adalah modal usaha, pengalaman, pendidikan, dan usia usaha (Sudarman, 2002: 17). Sedangkan Fitanto (2000) menjelaskan selain modal, faktor penting yang mempengaruhi produktivitas adalah umur, usia usaha, dan pendidikan.

\section{Rumusan Masalah}

Berdasarkan latar belakang yang telah diuraikan, permasalahan yang akan dibahas dalam penelitian ini sebagai berikut :

1. Bagaimana kinerja kelompok usaha binaan UP3HP di Kota Bengkulu.

2. Apakah modal, umur, usia usaha, dan pendidikan mempengaruhi kinerja kelompok usaha binaan UP3HP.

\section{Landasan Teori Industri Kecil}

Pengembangan industri kecil merupakan bagian yang tidak terpisahkan dari pembangunan industri dan ekonomi nasional. Subsektor industri kecil terbagi atas 5 jenis cabang usaha.

- Industri pengelolaan pangan

- Industri pengelolaan sandang dan kulit

- Industri pengelolaan kimia dan bangunan

- Industri kerajinan dan umum

- Industri pengelolaan logam

Industri kecil sendiri merupakan industri yang memiliki modal investasi untuk mesin, peralatan dan bangunan tidak lebih dari dua ratus juta rupiah dan dimiliki oleh warga negara indonesia (departemen perindustrian 1991: 3). Sedangkan menurut fricahyono: 1983 : 4) kelompok usaha industri kecil merupakan perusahaan yang memiliki kekayaan bersih tidak melebihi empat puluh juta rupiah.

\section{Pelayanan Pegembangan Pengolahan Hasil Pertanian (UP3HP)}

Dirtjen BPPHP Deptan (2002: 4) menyebutkan bahwa unit pelayanan pegembangan pengolahan hasil pertanian (UP3HP) adalah mekanisme pemberdayaan pelaku usaha yang bertujuan untuk memfasilitasi tumbuhnya industri pengelolaan kecil dan kerajinan rumahtangga. Tujuan dari program ini adalah sebagai upaya untuk memfasilitasi para pelaku usaha pengolahan hasil 
pertanian (tanaman pangan, hortikultura, perternakan dan perkebunan). Melalui program UP3HP ini nantinya diharapkan dapat menerapkan manajemen mutu, manajemen, penerapan teknologi tepat guna dan mempermudah akses sarana pengolahan dan permodalan serta pemasaran produk. Secara rinci tujuan dari program UP3HP ini adalah sebagai berikut:

- Meningkatkan nilai tambah

- Meningkatkan mutu dan daya saing

- Penyedian lapangan kerja

- Peningkatan pendapatan masyarakat

- Memberikan jaminan pasar

Pola dasar pengembangan program ini sebenarnya dirancang untuk mengatasi permasalahan kesenjangan antar subsistem produksi pengelolaan, manajemen usaha yang dihadapi oleh para pelaku usaha pengolahan hasil pertanian. Permasalahan tersebut menyangkut masalah kualitas bahan baku yang rendah, kuantitas yang terbatas dan tidak kontinyu (Dirtjen BPPHP Deptan 2002: 7)

Langkah langkah pengembangan UP3HP

Ada dua langkah yang dapat dilakukan dalam upaya pengembangan UP3HP. Langkah tersebut adalah pemberdayaan para pelaku usaha dan penetapan indikator keberhasilan untuk menentukan tingkat keberhasilan usaha.

Pemberdayaan pelaku atau kelompok usaha adalah upaya untuk memfasilitasi kelompok usaha agar mampu memanfaatkan potensi dan kreatifitasnya sendiri untuk melakukan usaha pengelolaan hasil pertanian guna mencapai kesejahteraan para anggotanya. Pemberdayaan yang dimaksud mencakup upaya-upaya yang tidak hanya terbatas pada aspek pengelolaan saja, tetapi juga aspek peningkatan sumberdaya manusia, aspek bisnis, aspek permodalan dan aspek pemasaran.

Selain pemberdayaan juga dibutuhkan indikator yang dapat digunakan guna menilai tingkat keberhasilan pemberdayaan tersebut. Ukuran ini biasanya dipakai secara berkala. Indikatorindikator tersebut antara lain ((Dirtjen BPPHP Deptan 2002: 15)

- Terjadinya peningkatan hasil atau produk pengolahan hasil pertanian (jenis, jumlah dan mutu) serta peningkatan pendapatan anggota binaan kelompok penerima manfaat program

- Tumbuhnya kelompok usaha binaan baru yang maju, berdaya saing dan mandiri dan mampu menjadi penggerak ekonomi didaerahnya

- Terjadinya peningkatan nilai tambah hasil pertanian dan tercapainya pemupukan (akumulasi) modal kelompok usaha binaan.

- Terjadinya perubahan usaha dari subsistem menjadi usaha pengolahan yang berorientasi komersil

- Tumbuhnya kemitraan usaha antar kelompok usaha dan dengan mitra usaha lainnya

Kinerja juga disebut performance yang berarti prestasi, pelaksanaan kerja atau pencapaian kerja. Menurut smith dalam Gaol (2006: 7) bahwa performance adalah "output drive from processes human or otherwise" dengan kata lain bahwa kinerja merupakan hasil keluaran dari suatu proses. Sumber lain menyebutkan Gaol (2006: 7) bahwa kinerja merupakan hasil kerja yang dicapai seseorang atau sekelompok orang dalam organisasi sesuai dengan wewenang dan tanggung jawab masing-masing. Dapat disimpulkan bahwa kinerja merupakan pencapaian hasil kerja sesuai dengan tujuan dan tanggung jawab masing masing. Ditinjau dari sektor usaha bahwa kinerja atau produktivitas dapat dinilai dari tingkat penghasilan yang dihasilakan (omzet). Dalam penelitian ini, indikator yang digunakan untuk menilai kualitas hasil usaha adalah omzet atau dalam istilah ekonomi sering di sebut dengan total revenue.

\section{Omzet}

omzet merupakan penerimaan produsen dari hasil penjualan outputnya. Beesarnya output itu sendiri ditentukan oleh jumlah output (quantitas) dan harga dari output (kualitas). Omzet adalah alat ukur dari kualitas kinerja secara kuantitatif maka pendekatan yang paling umum 
digunakan (Boediono 1984: 83). Dalam jangka pendek, output yang dihasilkan produsen dapat ditambah atau dikurangi dengan merubah jumlah input variabel yang digunakan.

$\mathrm{TR}=\mathrm{Q} \cdot \mathrm{PQ}$

Dimana:

TR : Penerimaan total produsen

Q : Jumah output yang dihasilakan

PQ : Harga dari output yang dihasilakan

oleh produsen

\section{Modal}

Modal atau capital merupakan segala jenis barang yang dihasilkan dan dimiliki masyarakat atau dengan kata lain kekayaan masyarakat (Von Bohn Bawerk dalam Daniel 2001: 74). Sebagian dari kekayaan tersebut digunakan untuk konsumsi dan sebagiannya lagidigunakan untuk memproduksi barang-barang baru (investasi). Bagian kekayaan yang digunakan untuk investasi inilah nantinya yang akan menghasilkan output. Jadi modal adalah setiap hasil atau produk yang dipergunakan untuk memproduksi barang selanjutnya.

Daniel (2001: 77) mengklasifikasikan modal menjadi dua jenis modal, yakni modal tetap dan modal bergerak.

a. Modal tetap

Modal tetap adalah modal yang digunakan dalam proses produksi yang dapat digunakan beberarpa kali. Meskipun barang-barang modal ini pada akhirnya akan habis juga dengan adaya akumulasi penyusutan. Modal tetap ini sama sekali tidak tererapa dalam hasil (output). Contohnya: mesin, pabrik, gedung.

b. Modal bergerak

Modal bergerak adalah modal yang digunakan dalam proses produksi yang hanya dapat digunakan satu kali. Dengan kata lain barang-barang yang habis pakai dalam proses produksi. Contoh modal bergerak: bahan mentah, plastik pengemasan, tepung untuk membuat kue, atau lainnya.

\section{Umur}

Umur adalah usia seseorang yang merupakan ukuran lamanya seseorang hidup. Oleh karena itu umur dapat mencermnkan pengalaman dan kematangan seseorang dalam kehidupan seseorang (Pricahyo, 1997: 35).

Meifitasari (1997: 10) menyatakan bahwa umur merupakan salah satu faktor yang berhubungan dengan tingkat keberhasilan seseorang. Seseorang yang berusia produktif, kemampuan kerjanya akan lebih tinggi dibandingkan dengan seseorang yang berada pada usia non produktif. Hal ini dikarenakan pada usia produktif seseorang mempunyai motivasi dan semangat serta tenaga yang kuat sehingga mampu melakukan kegiatan produksi.

\section{Usia usaha}

Departemen Tenaga Kerja RI (1993: 4) dalam Naibaho (2006: 16) menjelaskan bahwa usia usaha adalah jangka waktu didirikannya suatu unit usaha atau perusahaan. Dalam jangka waktu menjalankan objek usaha tersebut tentu seseorang akan menghadapi masalah-masalah dan tantangan kerja. Semakin lama seseorang atau perusahaan tersebut beroperasi maka pengalaman kerja dari pengusahanya akan semakin bertambah. Keahliaan yang dimiliki dari pengalaman usaha yang ditekuni akan mempengaruhi kualitas produk yang dihasilkan. Keadaan demikian dapat dimanfaatkan untuk mematok harga yang lebih tinggi. Selanjutnya efisiensi penggunaan sumber daya dan kualitas produk yang baik akan dapat mempengaruhi omzet (hasil penjualan) yang akan diperoleh. 


\section{Pendidikan}

Pendidikan merupakan upaya untuk memperbaiki dan meningkatkan pengetahuan, kemampuan, sikap, dan sifat kepribadiaan seseorang. Pendidikan bukan hanya sebatas pengetahuan yang berhubungan langsung dengan tugasnya, tetapi juga landasan untuk mengembangkan diri serta memanfaatkan sumber daya yang dimiliki (Handoko, 1992: 7).

Kualitas pendidikan yang baik dapat mempengaruhi seseorang dalam memproduksi suatu jenis barang dan jasa. Pendidikan akan mempengaruhi metode produksi serta melakukan inovasiinovasi agar usaha yang ditekuni dapat berjalan dengan efektif dan efisien. Kemmapuan menjalankan usaha secara efketif dan efisien akan berpengaruh terhadap omzet (total penjualan).

\section{Kerangka Analisis}

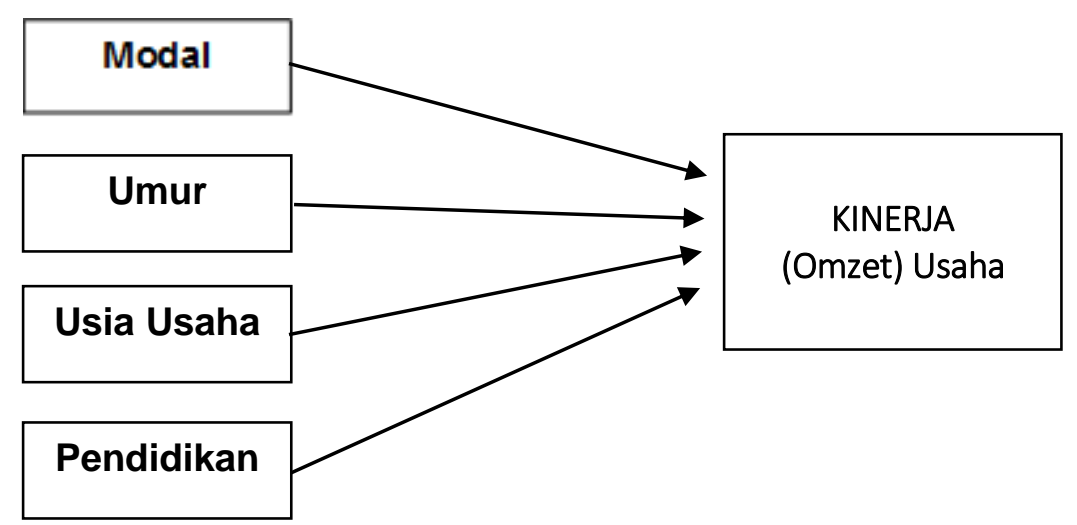

Gambar 1. Kerangka Analisis

\section{HASIL DAN PEMBAHASAN}

Berdasarkan hasil penelitian diketahui bahwa, jenis produk, harga, umur, usia usaha dan pendidikan responden bervariasi. Perbedaan ini selanjutna membedakan kinerja (omzet) yang diperoleh masing-masing. Omzet terkecil dari seluruh responden adalah Rp.200.000 (dua ratus ribu rupiah dan terbesar Rp.34.850.000 (tiga puluh empat juta delapan ratus lima puluh ribu per bulan. Mayoritas responden mempunyai omzet antara Rp.200.000-Rp.6.000.000 perbulan dengan rata-rata omzet sebesar Rp.7.963.700 perbulan.

Tabel 1. Responden berdasarkan omzet perbulan

\begin{tabular}{|c|l|c|c|}
\hline No & Omzet/bulan (Rp) & Frekuensi & Persentase \\
\hline 1 & $200.000-6.000 .000$ & $\mathbf{2 8}$ & $\mathbf{6 8 , 2 9}$ \\
\hline 2 & $6.000 .100-11.800 .000$ & 2 & 4,88 \\
\hline 3 & $11.800 .100-17.600 .000$ & 5 & 12,2 \\
\hline 4 & $17.600 .100-23.400 .000$ & 1 & 2,44 \\
\hline 5 & $23.400 .100-29.200 .000$ & 2 & 4,88 \\
\hline 6 & $29.200 .100-34.850 .000$ & 3 & 7,32 \\
\hline \multicolumn{2}{|c|}{ Jumlah } & $\mathbf{4 1}$ & $\mathbf{1 0 0}$ \\
\hline
\end{tabular}

Sumber: hasil penelitian

Tabel 1 dapat dilihat struktur omzet perbulan dari masing masing responden bervariasi. Sebagian besar memiliki omzet dibawah Rp.6.000.000 sebesar 68 persen lebih, selanjutnya 12,2 persen mempunyai omzet diatas Rp.23.400.000. artinya ada perbedaan yang mencolok antara usaha yang satu dengan yang lainnya. Banyak hal yang menyebabkan hal ini terjadi diantaranya, modal, jumlah tenaga kerja, umur, usia usaha dan lain sebagainya (hasil wawancara). 
Untuk menganalisa pengaruh modal, umur, usia usaha dan pendidikan terhadap omzet usaha anggota binaan UP3HP dapat digunakan analisis regresi linier berganda. Seluruh perhitungan digunakan program aplikasi komputer SPSS 12.0. hasil perhitungan tersebut dapat dilihat pada Tabel 2.

Tabel 2. Hasil perhitungan regresi liner berganda

\begin{tabular}{|l|l|l|l|l|}
\hline \multicolumn{1}{|c|}{ Variabel } & \multicolumn{1}{c|}{ Koefisien } & \multicolumn{1}{c|}{ Standar eror } & \multicolumn{1}{c|}{ t_hitung } & \multicolumn{1}{c|}{ Sig.t } \\
\hline Konstanta & $6,307 \mathrm{E}-2$ & 2,745 & 0,023 & 0,982 \\
\hline Modal usaha & 0,937 & 0,079 & 11,897 & 0,000 \\
\hline Umur & 0,609 & 0,562 & 1,084 & 0,286 \\
\hline Usia usaha & $-0,367$ & 0,158 & $-2,316$ & 0,026 \\
\hline Pendidikan & 0,153 & 0,496 & 0,309 & 0,759 \\
\hline R2 $=0,80$ & & & & \\
\hline R =0,89 & & & & \\
\hline Sig_F $=0,00$ & & & & \\
\hline F_hitung = 35,97 & & & & \\
\hline F_tabel $=5,74$ & & & & \\
\hline t_tabel $=2,042$ & & & & \\
\hline Sumber: & & & \\
\hline
\end{tabular}

Sumber: Hasil Pengolahan Data

Pada Tabel 2 dapat dilihat bahwa nilai $\mathrm{F}$ hitung $(35,97)$ lebih besar bila dibandingkan dengan $\mathrm{F}$ tabel $(5,74)$ dengan $\alpha 5 \%$. Setelah diuji (uji_F) maka secara bersama-sama atau keseluruhan, modal, umur, usia usaha dan pendidikan berpengaruh signifikan terhadap omzet yang diterima oleh anggota UP3HP di Kota Bengkulu.

Dari hasil perhitungan regresi linier berganda diperoleh persamaan sebagai berikut:

$\operatorname{Ln} Y=0,06307+0,937 \operatorname{LnX} 1+0,609 \operatorname{LnX} 2$

$$
-0,367 \operatorname{LnX} 3+0,153 \operatorname{LnX} 4+\mathrm{e}
$$

Artinya bahwa besarnya omzet (Ln Y) adalah 0,06307 ditambah 0,937 modal (LnX1) ditambah 0,609 umur (LnX2) dikurangi 0,367 usia usaha (LnX3) ditambah 0,153 (LnX4) ditambah faktor lainnya. Dari persamaan ini dapat dilihat arah pengaruh dari masing-masing variabel bebas/ independen (modal, umur, usia usaha dan pendidikan) terhadap variabel terikat/ dependen (omzet). Modal, umur dan pendidikan berpengaruh terhadap positif terhadap omzet sedangkan usia usaha berpegaruh negatif.

Dari Tabel 2 juga diketahui bahwa koefisien regresi (R2) sebesar 0,80 yang berarti 80 persen variasi naik turunya omzet usaha anggota UP3HP dapat dijelaskan oleh variabel independen, sedangkan 20 persen perubahan omzet tersebut ditentukan oleh variabel yang tidak termasuk didalam model yang diamati pada studi ini. Tingkat hubungan antara variabel dependen dengan variabel independen ditunjukkan oleh nilai koefisien korelasi (R) sebesar 0,89. Nilai tersebut mengindikasikan adanya hubungan (korelasi) yang kuat antara variabel independen (modal, umur, usia usaha dan pendidikan) dengan variabel dependen (omzet) yakni sebesar 89 persen. Secara parsial pengaruh dan hubungan antara masing-masing variabel independen terhadap variabel dependen sebagai berikut.

- Pengaruh modal terhadap omzet

Dari hasil perhitungan regresi linier berganda diketahui bahwa nilai t-hitung utnuk variabel modal adalah sebesar 11, 897. Angka ini lebih besar dibandingkan dengan t tabel (untuk $\mathrm{n}=41, \mathrm{k}=5$ ) sebesar 2,042. Artinya variabel modal secara parsial mempunyai pengaruh yang 
signifikan terhadap omzet. Besarnya pengaruh ini ditunjukkan oleh nilai koefisien regresi variabel modal sebesar 0,937 . Nilai ini mempunyai makna jika modal bertambah 1 persen maka omzet akan bertambah sebesar 0,937 persen.

- Pengaruh usia usaha terhadap omzet

t-hitung untuk variabel usia usaha adalah sebesar 2,316. Nilai ini lebih besar dibandingkan dengan nilai t-tabel $(2,316>2,042)$. Artinya secara parsial variabel umur mempunyai pengaruh yang signifikan terhadap omzet. Besarnya pengaruh ini ditunjukkan oleh nilai koefisien regresi variabel modal sebesar -0,367. Jika diperhatikan tanda minus itu menunjukkan arah hubungn yang bersifat negatif. Dengan kata lain, jika usia usaha bertambah 1 persen maka omzet akan berkurang sebesar 0,367 persen. Hal ini harus menjadi peringatan dan perhatian pemerintah khususnya dinas pertanian. Ada suatu kecendrungan yang kurang baik terhadap usaha kelompok UP3HP. Masalah ini membutuhkan pengkajian lebih lanjut pada studi lanjutan.

- Pengaruh umur terhadap omzet

t-hitung untuk variabel umur adalah sebesar 1,084. Nilai ini lebih kecil dibandingkan dengan nilai t-tabel $(1,084<2,042)$. Artinya secara parsial variabel umur tidak mempunyai pengaruh yang signifikan terhadap omzet. Kondisi ini bertolak belakang dengan penelitian terdahulu dan teori tentang kinerja yang telah disampaikan pada bab 2 .

Pengaruh pendidikan terhadap omzet t-hitung untuk variabel pendidikan adalah sebesar 0,309 . Nilai ini lebih kecil dibandingkan dengan nilai t-tabel $(0,309<2,042)$. Artinya secara parsial variabel pendidikan tidak mempunyai pengaruh yang signifikan terhadap omzet.

Dalam usaha UP3HP yang dituntut adalah ketelatenan, keuletan dan motivasi kerja, sehingga pendidikan kurang berpengaruh terhadap kinerja /omzet (hasil wawancara). Kondisi ini bertolak belakang dengan penelitian terdahulu dan teori tentang kinerja yang telah disampaikan pada bab 2 .

\section{Kesimpulan}

Berdasarkan hasil penelitian tentang faktor-faktor yang mempengaruhi kinerja usaha anggota binaan UP3HP di Kota Bengkulu, dapat disimpulkan beberapa hal sebagai berikut:

1. Kinerja (omzet) responden masih tergolong kecil, yakni rata-rata sebesar Rp.7.963.700/bulan, dengan mayoritas responden mempunyai omzet antara Rp.200.000 sampai Rp.6.000.000/bulan. Kecilnya omzet usaha tersebut disebabkan minimnya jumlah modal usaha.

2. Responden yang mempunyai usia usaha lebih tua cenderung mempunyai omzet yang lebih kecil.

3. Secara simultan modal, umur, usia usaha, dan pendidikan mempunyai pengaruh yang signifikan terhadap omzet usaha. Namun secara parsial modal mempunyai pengaruh yang positif signifikan terhadap omzet. variabel usia usaha secara parsial juga mempunyai pengaruh yang signifikan terhadap omzet, namun pengaruhnya adalah negatif. Sedangkan variabel umur dan pendidikan tidak mempunyai pengaruh yang signifikan terhadap omzet usaha.

\section{Saran}

1. Peningkatan kinerja (omzet) kelompok usaha binaan UP3HP di Kota Bengkulu harus menjadi perhatian semua pihak. Hal ini disebabkan kelompok usaha binaan UP3HP 
mempunyai potensi yang cukup besar untuk dikembangkan dalam upaya peningkatan pendapatan kelompok usaha binaan.

2. Instansi-instansi pemerintah maupun swasta diharapkan menjadi tumpuan untuk meningkatkan kinerja kelompok usaha binaan UP3HP. Terutama dalam peningkatan pemberian modal baik secara jumlah maupun kontinuitas.

3. Pemberian pelatihan dapat bermanfaat bagi para kelompok usaha binaan UP3HP di Kota Bengkulu terutama bagi para kelompok usaha yang mempunyai usia usaha lebih tua.

\section{DAFTAR PUSTAKA}

Aryanti. 2004. Peranan Koperasi Bagi Industri Tahu Tempe. Skripsi. Tidak diterbitkan. Fakultas Ekonomi Universitas Bengkulu.

Abdulrahman. 1992. Ensiklopedia Ekonomi Keuangan Dan Perdagangan. Jakarta: pradya paramitha.

Badan pusat statistik. 2003. Profil Industri Kecil Dan Kerajinan Rumah Tangga. Jakarta. Indonesia.

BKKSI. 2001, November. Pola Pembinaan Usaha Kecil Dan Menengah.

http://www.bkksi.or.id

Boediono. 1984. Ekonomi Mikro. Yogyakarta: BPFE

Daniel, Moehar. 2001. Pengantar Ekonomi Pertanian. Medan: Bumi Aksara.

Dirtjen BPPHP Deptan. 2002. Pedoman Umum Pelaksanaan Program Pengembangan Unit Pengembangan Pengolahan Hasil Pertanian (UP3HP).

Dirtjen BPPHP Deptan. 2002. Program Pengembangan UP3HP Unit Pengembangan Pengolahan Hasil Pertanian.

Esmara, hendra. 1986. Perncanaan dan Pembangunan Indonesia. Jakarta: PT. Gramedia.

Fitanto, Bahtiar. 2000. Analisa Struktural Pendapatan Pengrajin Rotan Kandensari. fitanto@satumail.com. 2007-03-21 19:02:45.

Fricahyono. 1997. Analisa Usaha Kecil. Jakarta: LPFE-UI

Gaol, Lampatar Lumban. 2006. Hubungan Pengalaman Kerja, Lingkungan Kerja, Penempatan Kerja Dan Self Eficiancy Dengan Kinerja Karyawan Pada Hotel Samudra Dwingka Bengkulu. Skripsi. Tidak diterbitkan. Fakultas Ekonomi Universitas Bengkulu.

Handoko, Hani, T. 1996. Manajemen. Yogyakarta: BPFE-UI

Machfuoed, Mas`ud. 2004. Kewirausahaan Suatu Pendekatan Kontemporer. Yogyakarta: UPP YKPN.

Mefitasari. 1997. Faktor-Faktor Yang Mempengaruhi Produktivitas Kerja Petugas Bumi Poetra. Skripsi. Tidak diterbitkan. Fakultas ekonomi Universitas Bengkulu.

Prawirakusumo, Soeharto. 2001. Ekonomi Rakyat (Konsep, Kebijakan Dan Strategi). Edisi pertama. Universitas gajahmada. Yogyakarta: BPFI. 
Simanjuntak, Payaman. 1995. Pengembangan Teori Bidang Sumber Daya Manusia. Universitas Indonesia. Jakarta: LPFE.

Singarimbun, Masri. 1989. Metode Penelitian Survei. Jakarta: LP3ES.

Sudarman, Ari. 2002. Teori Ekonomi Produksi, Analisis Fungsi Cobb Duoglas. Jakarta: PT Raja Grafindo Persada.

Sumarni, Murti-John, Suprihanto. 1998. Pengantar Bisnis (Dasar-DasarEkonomi Perusahaan). Edisi Ke ke 5. Liberty: Yogyakarta. 2003.

Supranto, J. 1991. Metode Riset, Aplikasinya Dalam Pemasaran, Edisi 5. Jakarta: Universitas Indonesia.

Tambunan, Tulus TH. Perekonomian Indonesia Beberapa Masalah Penting. Jakarta: Ghalia Indonesia.

Undang-Undang Republik Indonesia Nomor 9 Tahun 1995 Tentang Usaha Kecil. Departemen Kopraso dan Pembinaan Pengusaha Kecil.

Wibowo, 1988. Petunjuk Mendirikan Usaha Kecil. Jakarta. Swadaya 